\title{
Phenomenology of Writing Skill in Order to Provide Solutions to Improve Writing Skills
}

\section{Elahe Kalantari Dehaghi}

Ph.D. Student of distance education planning, Payame Noor University (PNU)

P.O. Box: 19395-3697 Tehran, IR of Iran.Email: kalantari_elahi@yahoo.com

Dr. Seyed Mahdi Sajjadi

Associate professor, Tarbiat Modares University, Tehran, Iran

\section{Dr. Mohammad Reza Sarmadi}

Full professor in educational philosophy, Payame Noor University (PNU) P.O. Box: 19395-3697, Tehran, IR of Iran

\section{Dr. Zohreh Esmaeili}

Assistant Professor, Department of Psychology and educational sciences Payame Noor University (PNU), P.O. Box: 19395-3697, Tehran, IR of Iran

Doi:10.5901/mjss.2015.v6n6s6p114

\section{Abstract}

History of study in the cognitive literature of writing skills, as one of the core skills of language, goes back to the eighties $A D$ (Fayazbakhsh, 2006). From the education field experts point of view, writing approach include a series of audio-visual, linguistic and perceptual capabilities, have known as the best vehicles and most widely field of creative thinking and mass production of artistic wisdom (Hadian, 2006) and as one of the major life, training and education skills, plays a decisive role in better living and academic achievement (Fayazbakhsh, 2006). In recent decade, which is coincided with the formation of the information age and the advent of fourth generation of technologies, namely information - communication technologies, training and $E$ learning with features such as Hypertext and Hypermedia (Rahmani, 2007), there has been a great emphasis on the use of writing skills (Zaman poor, 2010) in order to produce knowledge (Attaran, 2009). Due to the increasing development of the use of writing skills through the application of new learning technologies, this research pursues three primary goals: First, examine the characteristics of writing skills and the reasons of its importance. Second, reviews the concerns resulting from the use of writing skills in virtual spaces. Third, offers the guidelines in order to reduce concerns and improve writing skills among learners. The mentioned study has a qualitative approach. The method that is used in this research is documentary research. After gathering the information from library sources and websites, the concepts has been analyzed, interpreted and then concluded.

Keywords: Phenomenology, writing skill.

\section{Introduction}

In 1980, researchers and theorists in their studies about creating a variety of learning styles and cognitive changes, as a result found the usage of different writing method (Burke). Researches show that writing facilitates the perception and cognition more than prompt recall of information; it also helps to increase memory performance and individual performance on tests related to working memory. In addition, writing also helps to organize the beliefs, to clean bad opinions from working memory and to release the memory resources to process information more effectively. So writing causes the mechanism of clearance the unwanted emotional issues from working memory that lead to a more effective cognitive processing, it also uses another mechanism that is in the form of first and primary language and it gives the working memory better preparation to use the language in the past. Since long-term memory is dependent on working memory, studies have shown that writing, learning and organizing information in long-term memory also will increase. Facilitating the process of information in long-term memory and working memory through written assignments cause to perform complex cognitive tasks, to increase reading comprehension and text memory. Klein \& Boals (2001) argue that 
writing can facilitate cognitive performance (Linderholm \& Abrams, 2006) because writing is involved with a variety of cognitive processes and can also provide a variety of cognitive skills. These skills include beliefs translations; remodification of information, identification of relationships between beliefs, inferences extraction, making inferences, construction of large hierarchical structures and analysis (B. mith, F. Weiss \& J. Ferguson, 1987).

The notion that the act of writing creates new knowledge has been discussed for psychologists as their favorite subject for many years. For example, in the study of writing as an innovative activity, Luria \& Yudovich (1971) describe writing as a new and powerful thinking tool along with analyzing and self-display characteristics. Britton (1970) explains that writing provides a symbolic display of experiences and writing a lot influences on the organization of experiences and makes it more memorable. Gage (1986) on how to participate in the writing recognition in a part of his book (why write?) suggests that writing is clearer thinking, thinking that it can be tested, because writing is done on pages not invisible in mind. Writing is thinking that it can be stopped and tinkered. Writing is a way to keep long-term thinking and to time of studying the structures and defects, writing is a road to understand more clearly, thinking is an individual who travels on a paper and tries to find the words for ourselves (McGinley \&Tierney, 1988). Thus, writing involves of a variety of ideas (B. mith, F. Weiss \& J. Ferguson,1987). In experimental studies, Marshall (1987) and Newell (1989), the evidences suggest that writing as personal and interpersonal collaborate in thinking and learning (Kieft, 2006). Accroding to the evidences Vygotsky (1986) also suggests that there is a link between word and thought, because thinking does not exist, except by expressing it in words (Siemens, 2006). Also Olson(1985) confirm the dependence between thinking and writing and writing role in helping people to combine old and new knowledge and says: "Writers should use their memory to provide what they know, to review the information that has been produced and translated into speech or printed (Thomas \& Peterson, 1997). In this way, professional writers use various writing styles, and they are not limited to just one structure or style. They encounter the world real Obstacles and possess a variety of forms, strategies, knowledge and skills that can provide them in a flexible way to achieve their writing goals (Graham \& Perin, 2007). Also according to studies, the authors modify its processes, so that these processes tend toward a recursive algorithm (Burke). In addition, writers, use visual and kinesthetic thinking. They use different cognitive ways to produce various forms of information or deformation of the products. During exploratory thinking which is a creative thinking, the authors identify the opinions and information and the multiple possibilities for the production of documents or text are considered. During the exploratory writing, the writer extracts the potential content from long-term memory or external resource, and investigates the relationship between beliefs (B. mith, F. Weiss\& J. Ferguson, 1987). Sandra Perl, who published the influential process-based essay "Understanding Composing" (1980), is the editor of Landmark Essays: On Writing Process; she points out in the introduction, "Writing Process: A Shining Moment," that by the late 1980s "the scene of writing is more often understood not as a room in which a writer is isolated and alone, but as a room in which many voices reside, those that both shape the writer and to which he or she responds in return"(Vandenberg, Hum \& Clary-Lemon). Writing will let the reader to work as an author (Baldwin \& Hill, 2012) and to develop their critical literacy through their writing. (A. Langer\& Flihan, 2000).

The author starts Writing for a partner with what he has in mind. When he began writing, others disappear. When author extends his writing and words are used in the context of writing, the author will be lost and silent in the writing context, and it seems that he is writing for no one (Manen \& Adams, 2009).

Helene Cixous (1997) says on the mentioned characteristic that "this does not mean that the author is scoffing the readers, but on the contrary, he does not know who the readers are. He just knows that there are some people here (but who?)(Manen \& Adams, 2009). For example, in writing a love poem, it seems that a person is destroyed and recreated at the same time. In this way, the author phenomenology is facing the darkness and trying to see what is not seen. As Robert Frost said: "Writing is like falling in darkness." Here the meanings are intensified and are provided in speculative thought (Manen \& Adams, 2009). In comparison of writing with other language skills, writing moment is different from any other moment. While rewriting, we can assess the words, the value of meanings, review the text musical, make the words clear, measure the effect of text on the reader s' imagination, describe and classify assumptions, make our language and reconstruct the text again and again to gain confidence, just Call "Now and Now,". In contrast, while speaking, certain words are said and what is said or heard, cannot be edited back (Manen \&Adams, 2009). Vygotsky (1962) also believes that writing is a unique way to learn, and it is different from other language processes such as listening, reading and interaction because writing requires more analytical thinking and is a process that is engaged in meaning manufacturing. Emig (1977) believes that writing as a different operation, has many of the characteristics that psychologists have introduced on learning strategies. For example Emig claims that writing is a unique way to display power and a multiple way to learning, because when we are writing our essay, we are learning by doing, by a presage of what we do and by the symbolic representation of experiences (McGinley \& Tierney, 1988). Also, writing is a form of language processing. We learn writing by writing. Not only we learn to write, but also we write to learn (Burke). Therefore, many researchers 
believe that writing guarantees learning, because writing makes the person to be engaged in the process of linking the pieces of information in the communication and stating what has not been present so far. Martin (1975) states that the act of writing makes the person to have personal choice, thinking and breaking up, author is changed to a different person with a more obvious thinking and attitude. Van De Weghe (1987) explains that the process of writing the essay, is a mean for writer to creates moments of discovery or moments of conceptual development (McGinley \&Tierney, 1988). Mason (2001) suggests the use of writing to comment, thinking and communication, raises individual awareness and encourages people and it is known as a useful and valuable tool for the process of revising the knowledge (Akar, 2003) and experiences deformation (Graham \& Perin, 2007). Polanyi(1966) believed that the development of writing allows the person to exploit deep personal knowledge in an intelligent way and also let him to have the opportunity to pursue deep personal interests (Thomas \& Peterson,1997) and to have a passage to reflect the meanings and perceptions of individual minds (Siemens, 2006). Also writing is one of the first and most basic social activities (Vandenberg, Hum \& Clary-Lemon) and can contribute to personal growth and exploration the individuals as a learning tool, mental activity and complex communication process (Burke). According to Glatthom (1985), we write to find out (Thomas \& Peterson, 1997). Hayes and Flower (1981) claim that writing is a complex process of problem solving that the author use a collection of powerful innovations, such as planning, brainstorming, Simulating a reader's response as a tool for generating new ideas (McGinley \& Tierney, 1988). They also consider writing process as an essentially cognitive activity. However, some also tend to see it from a more cultural and social perspective (Barnard \& Campbell). Furthermore, the ability to write is selfcorrection (Warnock), because writing as a useful strategy is an attempt to enhance the better feeling health (Linderholm \& Abrams, 2006) and is an exciting activity, because it is the producer and creator (Burke). Florio and Clark (1982) believe that writing is a tool for knowing yourself and others (Thomas \&Peterson, 1997).

\section{Concerns about Writing on the Web}

In the contemporary period, fast-growing Internet, social technologies and invention of the Web-based tools 2 (Web to read / to write) with features such as low cost, ubiquity, accessibility and ease of use have provided equal and vast opportunities among people to write (Siemens, 2006) and this context is also more attractive than conventional software in teaching and learning environments (Brodanl, Hadjerrouit \& Hansen, 2011).

Warschauer (2003) noted that spread of computers and Internet, such as entering printed materials have made important changes in the technology of writing, why and how, the objectives, the nature of the audience, author, and a variety of written communications and are considered as significant factors in the development of writing and written communications (Barnard \& Campbell). New technologies have made writing at the center of social participation, and urban life in the communities in the twenty first century (Graham, Harris\& Hebert, 2011), have changed methods of reading and writing, and also have altered the traditional skills of students as readers or top writers (Atchison, 2004), contemporary writing is known as online writing (Manen \& Adams, 2009).

Expanding the use of information-communication technologies in writing field, have created various concerns of among the education community in general and among teachers in particular. These concerns are not about the teaching method to write, but it also refers to the type of use. Among these concerns, some are mentioned as follows:

1. Writing among learners generally occurs informally.

2. Learners often use writing in a graphical communications format. so graphical format have been dominant on text.

3. Plagiarism is facilitated.

4. Students who produce multimedia will lose the general approach goal which is writing and instead spend majority of time in completing fonts, colors or images (Warschauer, 2007).

5. The students have the possibility to access inappropriate content. Despite legislation and filtrations in order to prevent the students' access to inappropriate information, features, and ease of content creation, leading to an explosion in online content production is increasingly making the legislations and filtrations difficult.

6. Because of a series of policies and filtrations in schools, students use technology outside of school, and this limits their control over the practice of writing.

7. Inappropriate share by the students after the creation of online content is of other concerns in writing on the web.

8. Ease of copying and attaching online information, is another problem (Wagner, 2006).

9. With a flexible and dynamic hypertext written structure as an investment for learner, these documents can make the reading process difficult, especially for students who have less ability (Atchison, 2004).

10. The use of hypertext is the best way to educate and develop the conflicts, to deal with the promotion of 
controlled information and to impose beliefs on others. But the possibility of planning conflicting ideas just reinforce the differences, contrasts the views of people in many things, for example toward religion, and it strengthen the heterogeneity and inconsistency or divergence of behavior, in such a way that it is less possible to guide the students' behavior toward common and similar purposes (Imanzade, 2009).

\section{Concerns of the Writers in Virtual Environments}

The authors also have their own concerns, which are as follows:

1. They are always worried about users and learners while studying path to get lost, (Usborne), because the use of hypertext in online environments, has provided the possibility of distributed writing (B. mith, F. Weiss \& J. Ferguson, 1987). Such structure does not have a linear and hierarchical form, and each person can create his own guiding path (Marinella, 2007).

2. Authors have to write for various readers and search engines.

3. Attracting users' trust to study the website is another concern of writing on the web.

4. Because the data in the virtual environment is temporary and is constantly updated, the authors must provide their data before it's too late (Usborne).

\section{Conclusion}

Writing is considered as one of the necessary skills to success in work and education (Lenhart \& Arafeh, 2008) and great importance has been devoted to the use of writing in computer-based communications learners' learning in these environments (Garrison \& Anderson, 2004) so that computers have widely make it possible to write in any form or by any subject (Fahandej, 2004). Researches also show that students who were more capable of writing assignments and have replaced written instructions to verbal orders related the traditional and face to face learning are more successful in learning through information technologies (Farmahini Farahani, 2007). Thus the main tool for students to write creatively and communication is using ICT (Ebadi, 2006). Due to the expansion and diversification of information centers, schools and virtual universities and extensive growth of distance education and e-learning system in our country in recent decades (Ebadi, 2004), the importance of writing skills and trying to resolve the limitations in it growth path among learners is very important.

\section{Recommendation}

Recommendations to improve the writing skills of learners

1. Because a large number of learners due to laws, policies and filtrations in online pages, start writing outside of school, teachers must teach them the appropriate, responsible, ethical and safe use of technologies.

2. Discussing the principles and values of integrity, respecting copyright, fair use of issues and how to deal with inappropriate content help the students to understand the rules and responsibilities (Wagner, 2006).

3. Warschauer's Research(1999) showed that the duration of time which students spend on making multimedia or completing fonts, colors and images, depend on the expectations of their teachers. Teachers expecting writing professionally with a professional appearance and emphasizing on designing a website, will cause the learners not to pay attention to wiring but to appearance. On the other hand, lack of attention to designing the website can limit great opportunities for growth and new multimedia literacy of students (Warschauer, 2007).

4. Instructors must devote time in the curriculum to write and involve the students in various forms of writing (Graham, 2008). Experts agree on the opinion that the low quality writings among the students is due to the fact that they not asked enough to write (Glover\& Bruning,1990). Students should have a minimum of one hour in the process of writing, designing, rewriting or publication of their work (Graham, 2008). When students are given opportunities to express themselves, to organize and pursue their goals independently, they write their thoughts over what teachers expect. Assuring the students as writers strengthen their motivation for writing and gives learners the ability to guide their learning (Thomas\& Peterson, 1997).

5. The student's knowledge and understanding of writing should be increased. This is can be achieved by obtaining and providing information about the characteristics of good writing, various forms of writing, their goals. Also encouraging the students to read texts can provide information about how to organize the text, how to describe feelings and how to form sentences.

6. Interest, enjoyment and motivation for writing should be promoted in students. If the class is pleasant and 
supportive, students will enjoy writing more. To encourage them, their own Writings can be used to be encouraged and their writings can be linked to their life outside of school. Collaborating among students will make their writing more interesting. Students should be helped to become strategic authors.

7. In writing skills, the basic related skills should be taught.

8. Instructors can use the facilities of technological tools and software such as word processing to teach writing. In this software:

$>$ Reviewing and overviewing are easy.

$>$ The provided materials can be offered in the form of professional templates.

$>$ Typing is an easy tool to generate text by students who have kinesthetic problems.

$>$ In word processing software, there is the possibility to link to other programs including writing checks and other Office company software.

$>$ collaboration among authors through the use of computer networks and the Internet will increase (Graham, 2008).

$>$ One can also identify and present the students with a variety of digital media which are easy for learners to use (National Council of Teachers of English, 2008). In addition, a variety of games, multimedia, web sites can be used in teaching (Lenhart \& Arafeh, 2008).

9. To measure the progress and needs of students in writing skills, evaluation should be done. Evaluation is an integral part of teaching writing skill (Graham, 2008).

10. In order to use language professionally in writing, students control on the elements of language and communication for the different purposes, partners and context should be raised. When the students are writing for different purposes and partners, they are seeking for readers knowledge, their political and philosophical perspectives and looking their writings beyond the classroom context (Burke).

11. Students multiple education should be developed in a significant, complex and appropriate way.

12. The curriculum needs to be investigated to coordinate with changes and multiple educational models that include interactions increase, visual display and non-liner being of information for writers and readers.

13. Optimum opportunities should be provided for reading and writing on the web 2 .

14. The technical suggestions and Opportunities which is provided by teachers to understand the texts through multimedia for learners should be welcomed and encouraged.

15. Conditions should be provided that allow students to apply and build the related knowledge skills in real-world problems and provide possibilities to publish their results to world partners (National Council of Teachers of English, 2008).

16. We can encourage learners to prepare an outline, because researches have shown that the preparation of an outline, improve the quality of writing.

17. For writing, learners need access to information sources and evaluating the usefulness of sources used for writing.

18. Students should be led to the transfer of meaning. Good writers plan to convey meaning to others, but weak writers in their planning focus on the technical aspects of writing. Although appearance aspects of writing are important, but the main emphasis should be on meaning providence.

19. Students may be asked to reconsider their articles. Skilled writers know the most important part of writing as the process of revising their own writing. This makes it possible to correct and rewrite the writing.

20. The students can edit their classmates. Editing is an important skill that can be developed through constant practice.

21. The writing should be encouraged in all classes and teaching of writing should not be considered solely the responsibility of the language and literature teacher (Glover\& Bruning, 1990).

22. To prepare children for writing, storytelling can be used and story can be read to them eloquently. they not only hear an interesting and informative story, but also enjoy the sense of intimacy between reader and text books. Also expressive reading shows that the reader values and respects the writer and his writing. In addition, storytelling will promote the students on making sentences and idea creation.

23. Children stories should be listening to. Our active listening to the children, will teach them how to organize and express their thoughts. Even we can write the story as he is reading. When a child is waiting for your writing, he/she is more curious about continuing story and this causes him to think. In addition the child can be asked to make a play and perform it.

24. Printing and reproduction of children's literature can encourage them to continue writing.

25. Many children are afraid of being wrong or misspelled when writing, so they avoid writing. They can be said 
that while they writing for themselves, there is no need for correct spelling and writing of words. Only when the author intended his work to be published, there is a need for editing. If the child feels free or different about his work, will be more interested in writing.

26. When the child is writing, we should not interfere in his work and his curiosity. When he thinks, what is written, is really his own, he'll enjoy and write more. Indifference or persistent criticism about child writings makes it more difficult to write. After some encouragements, we can have a few constructive supervisions and criticism, and elegant of his writings, especially when he is on the starting path to write.

27. A child can be asked to write about impossible things. The more the story is not realistic, the better it would be. This make the child to use his/her mind, imagination more.

28. Sometimes it is necessary to write the first words to help children (Salahshour, 2004).

\section{References}

Akar, Hanife. (2003).Impact of Constructivist Learning Process on Preservice Teacher Education Students Performance, Retention and Attitudes.

A. Langer, Judith \& Flihan, Sheila. (2000). Writing and Reading Relationship: Constructive Tasks Data.

Atchison, Brad. (2004).Hypertext Literacy: Are We Teaching Students to Read and Write Hypertext? Journal of Educational Computing, Design \& Online Learning, Volume 5.

Attaran, M. (2009). Principles of ICT-based curriculum, Journal of Curriculum Studies, Vol. III, No. 12.

Baldwin, Clive \& Hill, Carolyn. (2012).Hypertext as an Expression of the Rhizomatic Self.

Barnard, Roger \& Campbell, Lucy. Sociocultural Theory and the Teaching of Process Writing: The Scaffolding of Learning in a University Context.

B. mith, John, F. Weiss, Stephen, \& J. Ferguson, Gordon. (1987).A Hypertext Writing Environment and its Cognitive Basis.

Britton, J. (1970). The student's writing. In E. Everetts (Eds.), Explorations in children's writing. Urbana, IL: National Council of Teachers of English.

Brodanl, Cornelia, Hadjerrouit, Said \& Hansen, Kristian Nils. (2011).Collaborative writing with Web 2.0 Technologies: Education Student perceptions, Journal of Information Technology Education, Volume 10.

Burke, Jim, Writing Across the Curriculum in High School.

Cixous, H. (1997) Rootprints: Memory and life writing. Helene Cixous and Mireille Calle-Gruber (London, Routledge).

Ebadi, R. (2004). Information Technology and Education, Tehran.

Ebadi, R. (2006). Power of the Internet to learn the transition from promise to practice, Tehran.

Emig, J. (1977). Writing as mode of learning. College Composition and Communication, 28, 122-127.

Fahandej, M. (2004). The application of technology (IT) in education.

Farmahini Farahani, M. (2007). Distance Education, a new vision of education in the country, Proceedings of the Second Conference on Educational Technology, University of Allameh Tabatabai.

Fayazbakhsh, Hoosein. (2006). Investigating the causes of dyslexia-dysgraphiain primary schools and ways to solve this problem, Shiraz, Iran's Sixth Annual Meeting of the Association for Curriculum Studies, Innovation in Curriculum of preliminary courses of Iran.

Florio, S., \& Clark, C.M. (1982). The function of writing in an elementary classroom. Research in the Teaching of English, 16, 115-130.

Flower, L, \& Hayes, J. R. (1981). Plans that guide the composing process. In C. H. Frederiksen \& J.F. Dominic (Eds.), Writing: Process, development and communication, Vol. 2 of writing: Thenature, development and teaching of written communication (pp. 39-58). Hillsdale, NJ: Erlbaum.

Gage, J. (1986). Why write? In D. Bartholomea \& A. Petrosky (Eds.), the teaching of writing (pp. 8-20). Chicago: National Society for the Study of Education.

Glatthom, A. A. (1985). Thinking and writing. In F. R. Link (Ed.), Essays on the intellect (pp.67-88). Alexandria, VA: Association for Supervision and Curriculum Development.

Glover, John A. \& Bruning, Roger H. (1990). Educational Psychology, Principles and application.

Graham, Steve. (2008).Effective Writing Instruction for All Students.

Graham, S. \& Perin, D. (2007).Writing Next: Effective strategies to improve writing of adolescents in middle and high schools- A report to Carnegie Corporation of New York. Washington, DC: Alliance for Excellent Education.

Graham, S., Harris, K., \& Hebert, M. A. (2011). Informing writing: The benefits of formative assessment. A Carnegie Corporation Time to Act report. Washington, DC: Alliance for Excellent Education.

Garrison, D.R. \& Anderson, T. (2004). E-learning in the 21st century, Translator: Attaran, M., Tehran.

Hadian, Majid.(2006).pathology of writing course (language) in grade five primary schools in Hamadan province and educational strategies to increase the effectiveness of its training program, Shiraz, Iran's Sixth Annual Meeting of the Association for Curriculum Studies, Innovation in Curriculum of preliminary courses of Iran.

Imanzade, A. (2009). The fundamental challenges of religious education in the Rhizomatic space.

Kieft, Marleen. (2006). Writing as a learning tool: Testing the role of students'writing strategies, European Journal of Psychology of Education, Vol. XXI, n'I1, p.7-34. 
Klein, K., \& Boals, A. (2001). Expressive writing can increase working memory capacity.

Journal of Experimental Psychology: General, 130, 520-533.

Lenhart, Amanda; Arafeh, Sousan, Smith, Aaron \& Rankin Macgill, Alexandra. (2008).Writing, Technology and Teens, The National Commission on Writing.

Linderholm, Tracy \& Abrams, Lise. (2006). The Benefits of Expressive Writing on Long-Term Memory Performance.

Luria, A. R., \& Yudovich, F. L (1971). In J. Simon (Ed.), Speech and the development of mentalprocesses in the child. Baltimore: Penguin, 1971.

McGinley, William\& J. Tierney, Robert. (1988).Reading and Writing as Ways of Knowing and Learning, The National Institute of Education.

Anen, Max van\& Adams, Catherine. (2009).The Phenomenology of Space in Writing Online, Educational Philosophy and Theory, Vol.41,No.1.

Marinella, Lizza. (2007).Active Reading and the Teaching of Writing.

Marshall, J.D. (1987). The effects of writing on students' understanding of literary texts. Research in the Teaching of English, 21 (1), 30 63.

Martin, N. (1975). Writing across the curriculum. London: Ward Lock.

Mason, L., (2001). Introducing talk and writing for conceptual change: A classroom study. Learning and Instruction, 11(4), 305-329.

Newell, G.E., Suszynski, K., \& Weingart, R. (1989). The effects of writing in a reader-based and text-based mode on students' understanding of two short stories. Journal of Reading Behaviour, 21, 37-57.

Olson, C.B. (1985). The thinking/writing connection. In A. L. Costa (Ed.), Developing minds: A resource book for teaching thinking (pp.102-107).Alexandria, VA: Association for Supervision and Curriculum Development.

Perl, Sondra. "Introduction: A Shining Moment." Landmark Essays on Writing Process. Ed. Sondra Perl. Davis, CA: Hermagoras, 1994.

Polanyi, M. (1966). The tacit dimension. New York: Doubleday.

Reading and Writing Differently. (2008).National Council of Teachers of English.

Rahmani, R. (2007). Educational technology, innovative approach to learning, Proceedings of the Second Conference on Educational Technology, University of Allameh Tabatabai.

Salahshour, M. (2004). Writing skills in children, Children's Book of the Month.

Siemens, George. (2006). Connectivism: Learning Theory or Pastime of the Self-Amused?

Thomas, Ruth\& Peterson, Debbie. (1997).Using Intensive Writing-to-Learn as a Means of Reducing Limitations on Learning in Large Classes, Technical Report Series, No.12.

Usborne, Nick. Writing for the Web: Seven Challenges every Writer and Copywriter Faces When Writing For the Web.

Vandenberg, Peter, Hum, Sue \& Clary-Lemon, Jennifer. Relations, Locations \& Positions: Composition Theory for Writing.

Van De Weghe, R. (1987). Making and remaking meaning: Developing purposeful, informal writing. English Quarterly, $20,38-51$.

Vygotsky, L S. (1962). Thought and language. Cambridge: Massachusetts Institute of Technology.

Vygotsky, L. (1986). Thought and language. Cambridge, MA: MIT Press.

Wagner, M. D. (2006). An Introduction to the Read/Write Web in Education. Gifted Education Communicator. Summer, Vol. 37, No.2.

Warnock, Scott .Teaching Writing Online Why \& How, National Council of Teachers of English.

Warschauer, M. (1999). Electronic literacies: Language, culture, and power in online education. Mahwah, NJ: Lawrence Erlbaum Associates.

Warschauer, M., Matsuda, P.K., Canagarajah, A.S., Harklau, L. \& Hyland, K. (2003).

Changing currents in second language writing research: A colloquium. Journal of Second

Language Writing, 12, 151-179.

Warschauer, Mark. (2007). Technology and Writing.

Zaman poor, E. (2010) .Stuying the factors affecting the academic performance of learners in higher education, based on the successful model of the learner's perspective, Journal of Curriculum Studies, Issue 16. 